\title{
THE INFLUENCE OF TRANSFORMATIONAL LEADERSHIP ON INDIVIDUAL KNOWLEDGE ACQUISITION, AND EMPLOYEE'S CREATIVITY IN PT. PINDAD (PERSERO)
}

\author{
Fajar Azmi Kurniawan ${ }^{1}$, Hamidah Nayati Utami ${ }^{2}$, Arik Prasetya
}

Faculty of Administrative Sciences, Brawijaya University, Malang, Indonesia

\begin{abstract}
This article aims to discuss the effect of independent variables namely transformational leadership on the dependent variable, namely individual knowledge acquisition and employee creativity. The method used is explanatory research with a quantitative approach. Data obtained through questionnaires. The sampling process uses proportional random sampling with 80 respondents. The analysis used is SEM-PLS with Smart PLS 3.0 software. From the analysis it was found that: 1) transformational leadership has a significant influence individual knowledge acquisition; 2) transformational leadership has a significant effect on employee creativity: 3) individual knowledge acquisition has a significant effect on employee creativity; 4) transformational leadership variables has a significant influence employee creativity through individual knowledge acquisition. This result has the potential to be considered for the evaluation of leadership style and policy formulation by leaders in PT. Pindad that associated with increasing employee motivation and learning motivation. So that the ideals of PT. Pindad (Persero) to contribute to the GFP (Global Fire Power) ranks can be realized.
\end{abstract}

Keywords: Transformational Leadership, Individual Knowledge Acquisition, Employee's creativity 


\title{
INTRODUCTION
}

Employee's creativity has benefits for both individual and organizations. That's why creativity research has been the main focus for more than four decades (Jain and Jain, 2017). Through the creativity of various solutions, it will appear to answer various challenges and problems that continue to change by the period. Further, the employee's creativity is a component of growth and competitiveness for a company (Singaribun and Effendi, 2006). Employee creative behavior is the production of new and useful ideas that raised by employees as a starting point for the creation of innovation (Moghimi and Subramaniam, 2013).

A company in Indonesia that integrates creativity content in its vision is PT. Pindad (Persero). This content is implicitly conveyed through the term innovation. This is theoretically to create innovation in the business field, then employees must have qualified creativity (Bagheri et al, 2013). Also considering that PT. Pindad (Persero), which is the only state-owned strategic industry in the field of defense equipment, has a large contribution in the field of state defense. It even influences the level of defense competitiveness in the eyes of the world. Therefore the leaders at PT. Pindad always strives to motivate all elements in the company to continue to develop themselves through operations, cooperation, and especially innovation which in the future will make a longterm contribution to Indonesia (Annual Report of PT. Pindad (Persero), 2017). However, there has been no evaluation of the leadership style adopted by the leaders of PT.Pindad (Persero), especially in the Munitions Division, Turen.

In other hand, when we view this case through Global Firepower (GFP) ranks in 2018, Indonesia has $15^{\text {th }}$ positions in the global scope. This position is still far below America and Russia which are in the 1st and 2nd positions. While in Asia, Indonesia's position is below Korea and Japan, which occupies the 7th and 8th positions. But in the scope of Southeast Asia Indonesia is located at the top level compared to other Southeast Asian countries such as Singapore and Thailand. Therefore a discussion on creativity related to PT Pindad's (Persero) vision in realizing product innovation as an effort to meet the needs of the state security system, as well as becoming a leading equipment and security manufacturer in Asia in 2023 through product innovation and strategic

\author{
Vol. 27, No. 3 December 2019 \\ (C) Centre for Indonesian Accounting and Management Research \\ Postgraduate Program, Brawijaya University
}


partnerships is one of the discussions interesting. This is because competition in the world of the armaments industry is quite strict.

Besides, the condition of companies with various limitations is a special concern to be studied, especially those relating to creativity, leadership and individual knowledge acquisition as supporting factors for the creation of innovation. If seen and linked to the Global Creativity Index presented by Martin Prosperity Institute in 2015 Indonesia has not been able to reach the top 25 of world countries with the title of the creative country. Of the total 139 countries, Indonesia is in position 115. This condition is still very far behind compared to some other Southeast Asian countries such as Thailand (82), Vietnam (80), Malaysia (63), Philippine (52), Laos (42) and Singapore ( 9). Martin Prosperity Institute measures the index of creativity through 3 (three) factors which include Technology, Talent and Tolerance, which results in the ranking obtained by Indonesia as a description of the three factors. This should be an introspection material for the good of the country and all components in it in the future, especially related to the strategic industrial field and specifically PT. Pindad (Persero).

The company's efforts to realize creativity cannot be separated from the role of the leader. This is because "one key situational impact on creativity is leadership " (Shin and Zhou, 2003). Some researchers believe that the employee's creativity will develop when leaders apply transformational leadership styles (Gong et al., 2009). Through the intrinsic dimension of motivation, transformational leadership can influence creativity (Amabile, 1998). Furthermore, Sosik et al., (1997) argue that, compared to other forms of leadership, transformational leadership is more influence in encouraging followers to think differently (out of the box) and to adopt generative and explorative thinking processes that produce more creative ideas and solutions.

The emergence of employee's creativity is not only due to transformational leadership factors. The process of acquisition of knowledge (individual knowledge acquisition) is indicated to contribute to the creation or realization of an employee's creativity. According to Soda et al., (2017) individual knowledge acquisition has an influence on employee's creativity by influencing individual cognitive structures. If it is understood Soda et al's opinion, explains that with new knowledge obtained by employees and organizations through the process of acquisition of knowledge it has tried to continue 
to survive the threat of destruction. This is supported by the opinion of Hsu (2016) that dedicated to acquiring new knowledge by learning, which is considered as the crucial investment for survival.

The discussion in this article believes that transformational leadership has a role for individual knowledge acquisition and employee's creativity. Jyoti and Dev (2015) argue, that leaders with transformational leadership styles provide much support for the learning and development process of employees by forming learning behavior, encouraging people to contribute to creating new ideas and ensuring the dissemination of knowledge which can ultimately encourage the emergence of creativity. Besides the influence of transformational leadership on individual knowledge acquisition and employee's creativity is supported by several studies conducted by previous researchers in various sectors such as Doeng et al. (2016); Eisenbeiss and Boerner (2013); Farahbood et al. (2012); Gong et al. (2009); Politis (2002); Rahmatipour and Alipour (2015); Shin and Zhou (2003); Soda et al., (2017); Suifan and Janini (2017). Furthermore, this discussion was conducted to investigate the influence of transformational leadership (TL) on individual knowledge acquisition (KA) and creativity (K). Thus the purpose of this research article is to discuss the significance of the influence of the following variables, 1) TL on KA; 2) TL to K; 3) KA to K, and 4) TL to K through KA.

\section{LITERATURE REVIEW}

In the study of leadership, there is a discussion that specifically addresses leadership that has an orientation to change to achieve organizational goals by involving various parties in the organization to achieve it. In this context, these parties are followers or followers who are often referred to as subordinates. Such leadership can be classified as transformational leadership. In general, transformational leadership can be understood as change-oriented leadership. By the nature of leadership, namely the existence of movements to achieve goals, then the purpose referred to here is change. The intended change is assumed to be a change in a better direction, opposing the status quo and being active (Lensuffie in Rondonuwu, 2011).

According to the opinion expressed by Burns in Simola et al (2012), define transformational leadership as a type of leadership in which interactions among interested 
parties are organized "around a collective purpose" in such a way that "transform, motivate, and enhance the actions and ethical aspirations of followers ". It is about defining transformational leadership as a type of leadership in which there is an interaction between interested groups, organizing shared goals, through a way that can change, motivate and enhance ethical actions and aspirations of followers. This definition also includes a leader action on acquiring knowledge of the employees.

In a theoretic paradigm, knowledge acquisition is a process of gaining knowledge and information directly from experts in their fields (Mykytyn, 1994). This also refers to employee involvement in certain activities that enable employees to recognize and obtain tacit and explicit knowledge. The other opinion states that the acquisition of new knowledge increases existing knowledge and skills (Rusly et al., 2015). Many studies said that skills often relates to creativity. In this context the main paradigm in the organization. So, creativity means the employee's creativity.

Oldham and Chummings (1996) said that individual creativity is those who identify the opportunities for new products. They may find a new use for existing methods or equipment or generate operable work-related ideas. It also means that creative individuals are those who tend to identify opportunities for new products. They can find new functions of existing methods or equipment, or produce new ideas related to work but can be operated. In other hands, Woodman, Sawyer, and Garffin in Jain and Jain (2011) said that "Employee creativity, a key component of human capital, involves generating ideas that are novel and valuable. Creativity refers to the creation of valuable and useful new products, services, ideas, procedures or processes by individuals working together in complex social systems. Employee creativity, a key component of human capital, involves generating new and valuable ideas. Creativity refers to the creation of new products, services, ideas, procedures or processes that are valuable and useful by individuals working together in complex social systems.

Regarding these literature, there are some relation between transformational leadership, individual knowledge acquisition, and employee's creativity:

\section{Transformational Leadership to Individual knowledge acquisition}

In the opinion of Politis (2002), there is a correlation between several leadership styles to the influence of the acquisition of employee knowledge. This is because the 
leader figure with his leadership style will contribute to the sustainability of the knowledge acquisition process. In the context of the current discussion, it is believed that one of the leadership styles in question is the transformational leadership style. As one example of the four dimensions inherent in transformational leadership, there is an idealized dimension of influence which in the opinion of Bass et al. (2003) that can be understood as the behavior of leaders who pay attention to each's needs for achievement and growth by acting as a coach or mentor. This illustrates that transformational leaders can become trainers and mentors for employees in the process of acquiring knowledge. Furthermore, according to the results of research conducted by Politis (2002); Rahmatipour and Alipour (2015) that obtained the results of leadership style variables with characteristics of participatory behavior, mutual trust and respect for ideas produced by subordinates proved to have a stronger impact on the knowledge acquisition process compared to leadership style characterized by task-oriented leader behavior or autocratic. Therefore, referring to some expert opinions and the results of research conducted by previous researchers, it can be concluded that there are influences and relationships between transformational leadership and individual knowledge acquisition.

From the explanation of the concept of the relationship between transformational leadership and individual knowledge acquisition, it can be illustrated that when in PT. Pindad (Persero) is a leader with a transformational leadership style with his role as a mentor or trainer in the employee learning process, so he will encourage the creation of individual knowledge acquisition more optimally. Therefore, the first hypothesis in this study was arranged as follows:

H 1 : Transformational leadership has a significant influence on individual knowledge acquisition in PT Pindad (Persero) Divisi Munisi Turen.

\section{Transformational Leadership to Employee's creativity}

Transformational leadership is one of the factors that can support the realization of an employee's creativity. According to Shin and Zhou (2003), One-key situational impact on creativity is leadership. In a transformational leader, four dimensions describe a leading figure with a transformational leadership style which includes idealized influence, individualized consideration, intellectual stimulation, and inspirational 
motivation which can be called four I's (Bass et al., 2003). The four dimensions of leadership or four I's according to Suifan and Janini (2017) are dimensions that can influence or contribute to the emergence of creativity. According to Sosik et al. (1997) compared to other forms of leadership, transformational leadership is more influence in encouraging followers to think differently (out of the box) and to adopt generative and explorative thinking processes that produce more creative ideas and solutions. On the results of research conducted by Shin and Zhou (2003); Gong et al. (2009); Eisenbeiss and Boerner (2013); Suifan and Janini (2017) obtained a finding that shows that transformational leadership has a significant influence on employee creativity.

Referring to the relationship between transformational leadership and employee creativity, as well as several earlier studies that show the results that it can be drawn a temporary answer that when in The Munitions Division of PT. Pindad (Persero) Turen has a leader with a transformational leadership style. Next, the four dimensions described can encourage the realization of an open mindset or out of the box that will bring out creativity and innovation. So thus transformational leadership can be described as influencing the creativity of employees at Pindad. Based on the description previous stated by the experts and the results of research conducted by previous research, the following hypotheses can be formulated:

H 2 : Transformational leadership has a significant influence on employee's creativity in PT Pindad (Persero) Divisi Munisi Turen.

\section{Individual Knowledge Acquisition to Employee's creativity}

Knowledge is a need that is never separated from human life. This is because, in essence, new knowledge will stimulate the occurrence and emergence of employee's creativity. Soda et al. (2017) argue that individual knowledge acquisition can influence an employee's creativity by influencing individual cognitive structures. A person's knowledge of a particular domain is important for the performance of creativity (Ford, 1996). Because to bring up new ideas that can be said to be creative or solutive requires qualified knowledge. According to Getzel (1975), the process of problem finding involves cognitive abilities to rearrange and redefine problems creatively. Furthermore, Ford (1996) also argues that when a person acquires or produces diverse knowledge, it 
will increase the ability of individuals (employees) to acquire new knowledge and utilize that knowledge in creative ways. According to the results of research conducted by Farahbood et al. (2012); Soda et al. (2017), there is an influence of individual knowledge acquisition on employee's creativity.

The third concept illustrates the relationship between the influence of individual knowledge acquisition with employee creativity compiled based on various earlier studies and research. This is then used as a basis by researchers to compile temporary answers, stating that individual knowledge acquisition or the process of finding knowledge will definitely influence the creativity of employees of The Munitions Division of PT. Pindad (Persero). The more knowledge gained will have an impact on increasing the cognitive abilities of employees as capital to create creative ideas. Based on the description above which discusses the relationship of individual knowledge acquisition with employee's creativity, it can be summarized as follows:

H 3 : Individual Knowledge acquisition has a significant influence on employee's creativity in PT Pindad (Persero) Divisi Munisi Turen.

\section{Transformational Leadership to Individual Knowledge Acquisition and Employee's creativity}

Influence of transformational leadership can function as a person who can make individuals acquire knowledge and skills related to tasks, which are key components to achieving new ideas or products (Doeng et al.,2016). According to Jyoti and Dev (2015) leaders with transformational leadership style provide a lot of support for the learning and development process of employees by forming learning behavior, encouraging people to contribute to creating new ideas and ensuring the spread of knowledge which in turn can encourage the emergence of creativity. In line with research Doeng et al. (2016) which states that transformational leaders who focus on individuals can influence creativity through skill development that comes from the knowledge acquisition process.

From the explanation of the concept of the relationship between transformational leadership and employee creativity through individual knowledge acquisition variables. Then it can be described that when in PT. Pindad (Persero) there is a figure of the leader with a transformational leadership style with his role as a mentor or trainer in the learning 
process of employees will encourage the creation of individual knowledge acquisition more optimally. So that the increase in employee knowledge that encourages increased cognitive ability will influence the thought process that triggers new ideas (out of the box) or raises employee creativity. Therefore, based on various earlier studies and studies, the fourth hypothesis in this study arranged as follows:

H 4 : Transformational leadership has a significant influence on creativity through individual knowledge acquisition in PT Pindad (Persero) Divisi Munisi Turen.

The elaboration has explained the concepts and theories that support the relationship between variables in this study. So as many as 4 hypotheses created in this study, where 3 hypotheses show a direct effect and 1 hypothesis shows an indirect effect. The first hypothesis describes the direct and significant influence of transformational leadership variables on individual knowledge acquisition in The Munitions Division of PT. Pindad (Persero). The second hypothesis shows the direct and significant influence of transformational leadership variables on employee creativity in The Munitions Division of PT. Pindad (Persero). The third hypothesis shows the direct and significant influence of individual knowledge acquisition variables on the creativity of employees of The Munitions Division of PT. Pindad (Persero). While the fourth or last hypothesis in the study shows the indirect and significant influence of transformational leadership variables on employee creativity through the individual knowledge acquisition variable in The Munitions Division of PT. Pindad (Persero). To describe the hypothesis in this study, the research hypothesis model arranged as in Figure 1 as follows: 


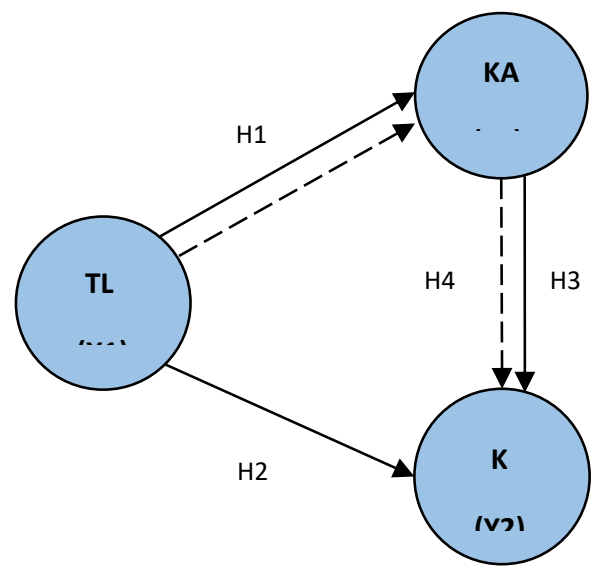

Figure 1. Hypothesis Model

\section{RESEARCH METHODS}

Based on the research objectives, that is to explain the influence of transformational leadership and individual knowledge acquisition on employee's creativity. Then the research method used is explanatory research with a quantitative approach. According to Singaribun and Effendi (2006), explanatory research is a study that explains the causal relationship between research variables through hypothesis testing. According to Sugiyono (2010), quantitative research can be interpreted as a research method based on the nature of positivism, used to examine certain populations or samples, sampling techniques are generally done randomly, data collection uses research instruments, quantitative/statistical data analysis to test a predetermined hypothesis. More Creswell (2010) describes quantitative research as methods to test specific theories by examining the relationship between the variables. The purpose of quantitative research is to explain, predict, and/or control, relationship, influence, causal phenomena through focused data collection from numerical data. This study uses primary data obtained through the distribution of questionnaires to obtain respondents' answers to statements that are arranged systematically by researchers. Analysis of inferential statistical data is processed using SPSS Version 17 and Smart-PLS version 3. 


\section{DATA COLLECTION}

This study, using a questionnaire as an instrument prepared and developed by the objectives and needs of the study. The questionnaire was designed to collect data accurately and minimize the occurrence of bias. The items in this study were measured using a 5-point Likert Scale ( $1=$ Strongly Disagree and $5=$ Very Set Uju $)$.

Table 1. Source of Questionnaire Preparation

\begin{tabular}{cccc}
\hline No. & Variabel & N of Item & Sources \\
\hline 1 & TL & 12 & {$[4]$} \\
2 & KA & 5 & {$[11,37]$} \\
3 & K & 10 & {$[34]$} \\
\hline
\end{tabular}

Source: Primary Data Processed, 2019

Table 1 contains data relating to the number of each item contained in each variable of this study. A total of 12 items of the statement of an item variable transformational leadership, 5 items of the statement of individual variables knowledge acquisition and 10 items are part of the variable employee's creativity. thus this study involved as many as 3 research variables and 27 items.

In a study, there is an object/subject of research which if taken as a whole, can be called a population. According to Sugiyono (2010) population is a region of generalization consisting of objects/subjects that have certain qualities and characteristics set by researchers to study and then draw conclusions. While according to Arikunto (2010) population is the whole subject of research. Based on the theory of the population, the population in this study involved 188 permanent employees of PT. Pindad (Persero) Division of Munition, Turen, Malang Regency. To determine the number of samples used proportional random sampling technique. According to Arikunto (in Handono, 2014) states that proportional random sampling is a sampling technique used because the number of subjects in each section has an unequal number.

Whereas according to the opinion put forward by Singh (2006) states that proportional sampling is a method of sampling which refers to the selection of compared samples with the size of the unit. This technique allows for each to have the same opportunity to become a sample in the study. From the process of calculating the sample by proportional random sampling method found a sample of 128 respondents. But after 
distribution to employees of PT. Pindad Division of Munitions, Turen, Kab. Malang, only 80 questionnaires were returned and could be processed by researchers. To measure the reliability of the instrument, a study of the validity of the research was measured, measured by the minimum requirement of $r$ value $\geq 0.30$ (Sugiyono, 2010). To measure the reliability of the research instrument, it is expected that the Cronbach Alpha value> 0.06 (Arikunto, 2010).

Table 2. Cronbach's Alpha Test Results

\begin{tabular}{clc}
\hline No & Variable & Cronbach's Alpha \\
\hline 1 & TL & 0.930 \\
2 & KA & 0.806 \\
3 & K & 0.905 \\
$* \mathrm{p} \geq 0.60$ & &
\end{tabular}

Source: Primary Data Processed by SPSS 17, 2019

Table 2 shows that all research instruments consist of 3 (three) variables in this study declared reliable. In the transformational leadership variable, the value of Cronbach's Alpha shows a value of 0.930 , for the individual knowledge acquisition variable it has a Cronbach's Alpha value of 0.806 and the employee's creativity variable has a Cronbach's Alpha value of 0.905 . The variables of this research are said to be reliable because Cronbach's Alpha value of each variable in this study has a value greater than 0.60 according to the opinion expressed by Arikunto (2010) so that it shows the consistency of measuring instruments if tested repeatedly.

\section{RESULTS AND DISCUSSION}

Data retrieval process carried out by researchers at PT. Pindad (Persero) Division of Munitions, Turen, Kab. Malang produced descriptive statistical data related to the demographic characteristics of the respondents. From a total of 80 respondents at PT. Pindad (Persero) Division of Munitions, The results obtained 63 (78.7\%) respondents with male sex and 17 respondents $(21.3 \%)$ were respondents with the female gender. Based on the classification of respondents by sex, it was found that out of a total of 80 respondents in this study were dominated by respondents with male sex and the rest were respondents with the female gender.

\section{Vol. 27, No. 3 December 2019 \\ (C) Centre for Indonesian Accounting and Management Research Postgraduate Program, Brawijaya University}


Furthermore, findings related to the characteristics of respondents based on age classification. From the findings of field researchers found that respondents $d$ ith age range 46-50 years 22 respondents (27.5\%) were respondents who dominated respondents characteristics by age, followed by respondents with ages ranging from 51 to 55 years 21 respondents (26.2) and so on were respondents with an age range of 26-30 as many as 16 respondents, $31-35$ as many as 10 respondents, 41-45 as many as 6 respondents, 36-40 as many as 4 respondents, and the least percentage was respondents with an age range of 21-25 as many as 1 respondent .

For the classification of respondents based on the level of education, it can be seen in Table 3 which shows that respondents with a high school education level of 47 respondents $(58.7 \%)$ were respondents who dominated the characteristics of respondents based on education level followed by respondents with bachelor degree education levels is 22 respondents $(27.5 \%)$. In the classification of respondents based on the tenure presented in Table 3, it can be seen, respondents with a working period of 26-30year $(33.7 \%)$ are the respondent who dominates the characteristics of respondents based on the period of employment.

Table 3. Characteristics of Respondents

\begin{tabular}{|c|c|c|}
\hline \multicolumn{3}{|c|}{ Characteristic } \\
\hline Gender & & \\
\hline Male & 63 & 78,7 \\
\hline Female & 17 & 21,3 \\
\hline Age & & \\
\hline 21 to 25 Years - Old & 1 & 1,3 \\
\hline 26 to 30 Years - Old & 16 & 20,0 \\
\hline 31 to 35 Years - Old & 10 & 12,5 \\
\hline 36 to 40 Years - Old & 4 & 5,0 \\
\hline 41 to 45 Years - Old & 6 & 7,5 \\
\hline 46 to 50 Years - Old & 22 & 27,5 \\
\hline 51 to 55 Years - Old & 21 & 26,2 \\
\hline
\end{tabular}


92 The Influence Of Transformational Leadership On Individual. . . . .

\section{Educational Level}

Bachelor Degree

Diploma 3 (D3)

22

27,5

Diploma 2 (D2)

7

8,7

Diploma 1 (D3)

3

3,8

Senior High School

1

1,3

Tenure of Service

\begin{tabular}{lrr}
$1-5$ Year & 25 & 31,3 \\
$6-10$ Year & 9 & 11,3 \\
$21-25$ Year & 12 & 15,0 \\
$26-30$ Year & 27 & 33,7 \\
$31-35$ Year & 7 & 8,7 \\
\hline
\end{tabular}

Source: Primary data processed, 2019

Inferential statistical analysis in this study was conducted using SEM-PLS which consisted of three stages of analysis. These stages consist of an analysis of the measurement model ( outer model), analysis of the structural model ( inner model ) and the research hypothesis test. Good research is expected to have composite reliability values > 0.8, with Cronbach Alpha> 0.6 for all constructs and have AVE values> 0.5 (Rumbewas, 2016).

Table 4. Construct reliability and validity

\begin{tabular}{cccc}
\hline Variable & $\begin{array}{c}\text { Cronbach's } \\
\text { Alpha }\end{array}$ & $\begin{array}{c}\text { Composite } \\
\text { Reliability }\end{array}$ & AVE \\
\hline TL & 0,931 & 0,941 & 0,569 \\
KA & 0,808 & 0,866 & 0,565 \\
K & 0,907 & 0,923 & 0,544 \\
\hline
\end{tabular}

Source: Primary data processed, 2019

Table 5. R Square 


\begin{tabular}{lc}
\hline Dependent Variable & $\boldsymbol{R}$ Square $\left(\boldsymbol{R}^{2}\right)$ \\
\hline KA & 0,414 \\
K & 0,617 \\
\hline
\end{tabular}

Source: Primary data processed, 2019

In the SEM-PLS model to find out the results of the overall goodness of fit can be known from Q 2 (predictive relevance). If the Q- Square value is greater than zero, it indicates that the exogenous latent variable has predictive relevance to the endogenous latent variables it influences (Solihin and Retno, 2012). Through table 5, the calculation of $\mathrm{Q} 2$ is arranged as follows:

Value Q 2 = 1 - (1- R 12 ) x (1- R 22 )

Value of Q 2 = 1 - $(1-0,414) \times(1-0,617)$

The value of Q $2=1-0,2244=0.775$

Referring to h acyl of Q 2 above calculations then showed Q 2 at 0.775 . The results of Q 2 indicate that the magnitude of the diversity of data in this study can be explained by a structured model designed with a value of $77.5 \%$, while the remaining $22.5 \%$ is explained by other factors outside the model. Testing SEM-PLS analysis for hypothesis testing is done by bootstrapping.

Table 6. Path Coefficient Direct influence

\begin{tabular}{clccc}
\hline Variable & $\begin{array}{c}\text { Original } \\
\text { Sample }\end{array}$ & $\begin{array}{c}\text { Standart } \\
\text { Deviation }\end{array}$ & T Statistics & $\begin{array}{c}\mathbf{P} \\
\text { Values }\end{array}$ \\
\hline TL>KA & 0,644 & 0,083 & 7.792 & 0,000 \\
TL $>$ K & 0,455 & 0,105 & 4,333 & 0,000 \\
KA $>$ K & 0,416 & 0,096 & 4,278 & 0,000 \\
\hline
\end{tabular}

Source: Primary Data Processed, 2019

Table 7 Path Coefficient Indirect Influences

\begin{tabular}{lcccc}
\hline Variable & $\begin{array}{c}\text { Original } \\
\text { Sample }\end{array}$ & $\begin{array}{c}\text { Standart } \\
\text { Deviation }\end{array}$ & $\begin{array}{c}\text { T } \\
\text { Statistics }\end{array}$ & $\begin{array}{c}\mathbf{P} \\
\text { Values }\end{array}$ \\
\hline TL>KA>K & 0,265 & 0,073 & 3,607 & 0,000
\end{tabular}

Source: Primary Data Processed, 2019 
Table 6 and Table 7 show the results of hypothesis testing both directly and indirectly. To find out further, the following will be discussed in each of the hypotheses in this study. First, influence TL (X) on KA (Y 1 ) shows a coefficient of 0.644 with a significant value of 0.000 smaller than 0.05 with a t-statistic value of 7.792 more than the t-table value of 1.991. The significance value in this study is less than $0.05(\mathrm{P}<\alpha)$ therefore $\mathrm{H} 0$ is acceptable $\mathrm{Ha}$ is rejected. The first hypothesis (H1) of this study shows the significant influence of TL (X) variables on KA (Y1) which shows that transformational leader figures significantly influence individual knowledge acquisition. This result is in line with the opinion Politis (2002) that there are links between several leadership styles to the influence of employee knowledge acquisition. One of the leadership styles is transformational leadership, in the opinion Bass et al., (2003) through the idealized dimension of influence leaders to pay attention to each's needs for achievement and growth by acting as a mentor or coach.

This is what underlies that leadership with transformational style influences the acquisition of employee knowledge by encouraging employees to carry out knowledge acquisition processes. Furthermore through the inspirational motivation dimension Leaders behave by motivating people around them, by giving meaning and challenges to the work of their followers. The spirit of individuals and teams is intrigued. Enthusiasm and optimism are displayed. The leader encourages followers to imagine interesting future conditions, which followers can finally dream of). From the inspirational motivational dimension, the enthusiasm of employees to carry out the knowledge acquisition process will be aroused, this is also inseparable from how the leader provides a picture in the future if the knowledge acquisition process can be taken seriously.

Referring to PT. Pindad (Persero) as a strategic company engaged in providing defense equipment countries with cultures that tend to be mechanistic and culturally close to military organizations will certainly have a rule that is a bit straight with authoritarian leaders, but in reality there is a possibility that there is a leader with a transformational leadership style so that the process of knowledge acquisition in the company can be carried out. It can show that the company once headed by leaders with transformational leadership style as well as Baharudin Jusuf Habibi, other than that most of the directors 
is a leader who has a background g professional education nonmilitary although the commissioners largely led by a leader with a background military institution.

If viewed from the values of PT. Pindad (Persero), one of which is "learning", PT. Pindad (Persero) emphasizes the people in the company to continue learning without stopping, teaching without stopping, developing themselves, making continuous improvements as a guide for transformational leaders in applying their leadership style. Corporate values are then implemented through knowledge sharing and knowledge acquisition programs, both formal and non-formal, aimed at meeting the knowledge needs of employees. Programs designed and implemented by the company include leadership programs, engineering, and production techniques, company management, basic on training, and student work or study assignments at universities both at home and abroad. Based on the implementation of education and training in 2017, the realization of Training hours was 82,716 hours or 33.5 hours per person.

When compared with 2016, the hours of Training people increased by $59.90 \%$, where the hours of Training people were 49,543 hours or 19.77 hours per person. In total, the influence of training in 2017 reached $88.99 \%$. The implementation of the process is certainly inseparable from the role of a leader who can become a mentor and become a party that motivates, directs and supports employees in carrying out the knowledge acquisition process. Furthermore, the results obtained from this study are in line with the results of the research conducted by Politis (2002); Rahmatipour and Alipour (2015). The results of previous investigators Secondly study showed a significant relationship between the leadership and influence of the transformational individual knowledge acquisition. The research conducted by Rahmatipur and Alipour showed significant results with a significance value of 0.049 . Whereas in Political research the results found that the attributes of transformational leadership influence the knowledge acquisition attribute. Therefore, based on the results of studies that discuss the influence of transformational leadership towards knowledge acquisition individual variables showed significant influence.

The influence of TL (X) on K (Y2) shows the path coefficient value of 0.455 with a significance value of $0.000(<0.05)$ and the $t$-statistic value of 4.333 is greater than the t-table value $(>1.991)$. The significance value indicates a value less than $<0.05(\mathrm{P}<\alpha)$ 
therefore $\mathrm{H} 0$ is accepted and Ha rejected. The second hypothesis (H2) in this study shows the significant influence of TL (X) on K (Y 2 ). This result is in line with the opinion Shin and Zhou (2003) which states that the one key situational impact on creativity is leadership. This basis reinforces that a leader is a determining factor in creating creativity. If studied, leaders have a diverse leadership style, but in this context, transformational leaders are the right leadership style. This is because in a transformational leader there are four dimensions that describe a leading figure with a transformational leadership style which consists of idealized influence, individualized consideration, intellectual stimulation, inspirational motivation (Bass et al., 2003). The four dimensions of transformational leadership are instruments of transformational leadership that can influence employee creativity.

Through the transformation of intellectual stimulation, transformational leaders stimulate followers to try to innovate and be creative by questioning assumptions, reformulating a problem and using a new approach to a long-established situation. New creative ideas and solutions to problems that are collected by followers, those included in the process of damaging problems and finding solutions). Furthermore, through idealized influence, these leaders were admired, respected, and trusted. Followers identify with and want to emulate their leaders. Among the things that leaders do to get awards from their followers is to consider the needs of followers for their own needs.

Leaders share risks with followers and are consistent in leading by paying attention to basic things such as ethics, principles, and values. If the leader has a creative nature, it can be said that the employee will be inspired to become a creative figure similar to their leader. When viewed from the condition of the employee, PT Pindad (Persero) Division of Munitions is being and has carried out a creative process that produces an idea or idea, policy, method, or an innovation that can eventually be applied to support the company in the face of competition. The form of creativity carried out by employees can be seen through the results of the annual report of PT. Pindad (Persero) 2017. From the annual report listed in the award section of the innovation results, the Munition Division received an award for the findings of the ideas and work process design of an object or function of work including "modification and multifunction of 5 caliber munition stacking machines, $56 \mathrm{~mm}$, human-machine interface optimization on the stacking stacking machine, made 
delay (modern technology safe and efficient), MU splashes save KU and optimization of the process of making metallic box supporting houses from 4 processes to 3 processes ".

The findings illustrate that the Division of Munitions has carried out the creative process to increase the value of a work process, product or production machine that is used to support the company's production activities. The process is certainly inseparable from the role of the leader who can facilitate, provide encouragement and become a mentor to employees so that ultimately able to make employees motivated to be more creative. Besides, the results and study of the second hypothesis are in line with the research Shin and Zhou (2003); Gong et al. (2009); Eisenbeiss and Boerner (2013); Suifan and Janini (2017).

In Shin \& Zhou's research, it was found that transformational leadership affected employee creativity, Gong research, Huang \& Farh (2009) showed that employee creativity had a positive relationship with supervisor ratings and performance in four quarters with values $(=0.84 \mathrm{p}<0.01)$. Eisenbeiss and Boerner's study (2013) showed the results of a positive and significant relationship between transformational leadership and employee creativity with scores $(\beta=0.208 ; \mathrm{p}<0.01)$ and in Suifan \& Janini $(2017)$ research the results of transformational leadership had a significant influence on employee creativity. Therefore based on the results of a study that discusses the influence of transformational leadership variables on employee creativity variables, the results of significant influence are obtained.

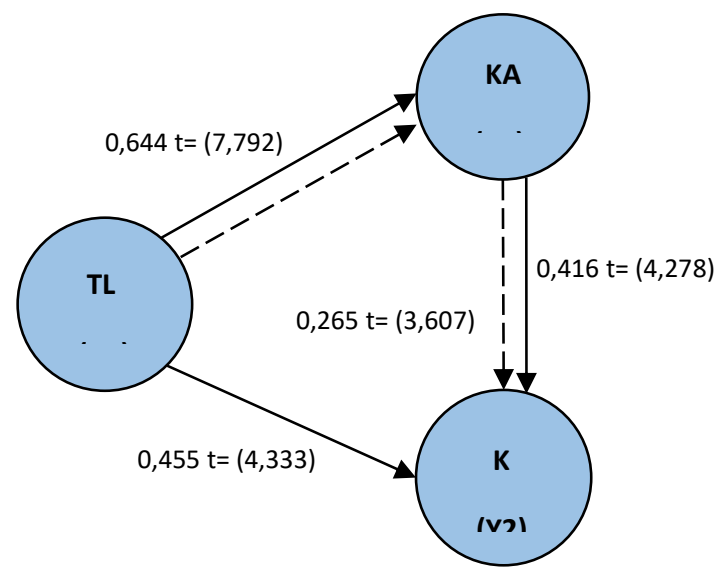

Figure 2. Hypothesis Model Test 
The influence of KA (Y 1) on K (Y 2) shows the path coefficient value of 0.416 with a significance value of $0,000(<0.05)$ and statistical value of 4.278 greater than the value of t-table (>1.991). The significance value of this study shows a value of less than $0.05(\mathrm{P}<\alpha)$ therefore $\mathrm{H} 0$ is accepted and $\mathrm{Ha}$ is rejected. The third hypothesis $(\mathrm{H} 3)$ of this study shows the significant influence of the KA variable (Y 1) on K (Y 2). These results indicate that the knowledge acquisition process can stimulate employees to be more creative. (Ford, 1996) argues, when someone acquires or produces diverse knowledge, it will increase the ability of individuals (employees) to acquire new knowledge and utilize that knowledge in creative ways. Source of knowledge at PT. Pindad is diverse both obtained through formal and non-formal processes and has also been emphasized in the company's value system regarding "learning" points. This has led to a variety of creative processes in the Munition Division with a manifestation of innovation results which in 2017 in the annual recapitulation of the Munisi Division company received an award for innovation results to improve the quality and quantity of the company's production.

These results can be seen through the acquisition of the Munisi Division award "Modification and multifunction $5.56 \mathrm{~mm}$ caliber munition stacking machine, humanmachine interface optimization on the stacking machine, delay technology (safe and efficient modern technology), MU splashes save KU and optimization of the manufacturing process metallic box support houses from 4 processes to 3 processes ". In addition to the company's vision, it has been emphasized that in 2023 Pindad has a target to become a leading equipment and security manufacturer in Asia through efforts to product innovation and strategic partnerships demanding that all parties in the company continue to learn and create creative thoughts so that this vision can be achieved. This condition is supported by the results of research that show the mean value of answers for individual variables, knowledge acquisition and employee creativity each shows a value of 4.24 for knowledge acquisition individual variables and 4.08 for employee creativity variables. This path coefficient value indicates a significant direct relationship between individual knowledge acquisition and a value of 0.411 and significant value of 0,000 .

The results of this study are in line with the research of Farahbood et al. (2012) and Soda et al. (2017) which shows the existence of individual knowledge acquisition 
towards employee creativity. In the Farahbood et al study, results obtained showed that knowledge acquisition had a positive and significant influence on school managers' creativity with values $(\mathrm{p}=0.000, \mathrm{r}=0.645)$, while in the study of Soda et. The results of knowledge acquisition have a positive and significant influence on employee creativity with a value $(\beta=0.47, \mathrm{p}<.05)$. Therefore, based on the results of a study that discusses the influence of the Individual knowledge acquisition variable on employee creativity variables, the results of significant influence are obtained.

The indirect influence of TL (X 1) on K (Y 2) through KA (Y 1) shows the path coefficient value of 0.265 with a significance value of 0,000 smaller than 0.05 with a tstatistic value of 3,607 more than the t-table value of 1,991. The significance in this study is less than $0.05(\mathrm{P}<\alpha)$ therefore $\mathrm{H} 0$ is acceptable $\mathrm{Ha}$ is rejected. The fourth hypothesis (H4) of this study shows the significant influence of TL variable (X) on variable K (Y 2) through the KA variable (Y 1). This result is in line with the opinion (Jyoti and Dev, 2015), that leaders with transformational leadership styles provide much support for the learning and development process of employees by forming learning behavior, encouraging people to contribute to creating new ideas and ensuring the dissemination of knowledge in finally it can encourage the emergence of creativity. From this point of view, it shows that through a transformational leadership style a leader can encourage employees by becoming mentors and facilitators to carry out the learning process through knowledge acquisition that has an impact on increasing cognitive skills so that employees' cognitive better than before will stimulate employees to think and creative behavior.

As previously explained, the educational programs implemented by companies are diverse, intending to increase cognitive abilities as capital to create creativity. Various types of education are implemented through knowledge sharing and knowledge acquisition programs, both formal and non-formal, aimed at meeting the knowledge needs of employees by the development of challenges and existing environmental conditions. Programs designed and implemented by the company include leadership programs, engineering, and production techniques, company management, basic Training, and student work or study assignments at universities both at home and abroad. The emergence of creative behavior due to leadership and acquisition of knowledge will be a solution to the various problems being faced. The results and studies of this study are in 
line with the research conducted (Doeng et al., 2016) which shows that skill development mediates the relationship between transformational leadership that focuses on individuals and creativity. The study of Doeng et al (2016) illustrates that transformational leaders who focus on individuals can influence individual creativity through skill development that comes from the knowledge acquisition process. Previous research conducted by Doeng et al (2016) reinforced the opinion of Amabile (1998), Anderson et al, 2014 and the results of indirect influences obtained from the testing of the seventh hypothesis of this study. Therefore, based on the results of a study that discusses the influence of transformational leadership variables on employee creativity variables through individual knowledge acquisition variables, the results are significant.

When viewed from the results of the analysis, it seems that there is a significant relationship between transformational leadership, individual knowledge acquisition, and employee creativity both directly and indirectly. The results of the analysis also illustrate that there is a transformational leader who can encourage employees to continue to explore knowledge through various means or media in seeking new knowledge by acting as a mentor or as a figure who provides examples and support for continuing to learn to gain knowledge. So from the encouragement of transformational leaders and individual knowledge acquisition processes, creative ideas will create for the realization of innovation.

If it is related to the State, the description of the results of this analysis shows that PT. Pindad (Persero), which is the only strategic industrial BUMN in the defense sector, has strived to continuously improve the quality and quantity of innovation through these three research variables (transformational leadership, individual knowledge acquisition, and employee creativity). When improvements to the potential of human resources in it continue to be improved to bring up new findings that are beneficial to the company, then this is also a manifestation of efforts to increase national defense and security in the form of various innovations in the field of defense equipment. Also, when the country's defense equipment was produced by PT. Pindad (Persero) has competitiveness in the global industry, the company's vision to become a leading producer of defense and security equipment in Asia by 2023, through product innovation efforts and strategic partnerships may be realized.

\author{
Vol. 27, No. 3 December 2019 \\ (C) Centre for Indonesian Accounting and Management Research \\ Postgraduate Program, Brawijaya University
}




\section{CONCLUSION}

Based on the study and the process of data analysis carried out on transformational leadership, individual knowledge acquisition, employee creativity at PT. Pindad (Persero) Division of Munitions, Turen, Kab. Malang obtained research results that showed a significant influence of transformational leadership variables on individual knowledge acquisition variables. The second result shows a significant influence on transformational leadership variables on employee creativity variables. Third, the results obtained show a significant influence of the individual variable knowledge acquisition on employee creativity variables. And fourth, the results of the existence of a significant influence of transformational leadership variables on employee creativity variables through individual knowledge acquisition variables.

The results of this analysis give an overview of the conditions of leadership in The Munitions Division of PT. Pindad (Persero), Turen Malang, especially the transformational leadership style with the perspective of its influence on individual knowledge acquisition and employee creativity. So from the results of this analysis, it is expected that PT. Pindad (Persero) as the only state-owned company engaged in the provision of state defense equipment can pay more attention to the potential possessed by employees by increasing employee cognitive abilities. One way can be achieved with the support of leaders who carry out transformational leadership styles that encourage the process of individual knowledge acquisition on an ongoing basis. Various forms of knowledge acquisition activities can be pursued in various ways by what has been stated by Ryu et al (2005), namely through three stages including Learning from others, learning by doing and learning by investment.

Learning from others is the process of gaining knowledge using formal and informal education both inside and outside the organization. For example in the formal sector researchers give advice to companies to increase the number of formal education programs that can be pursued by employees through educational institutions such as in leading tertiary institutions both at home and abroad from undergraduate to doctoral levels. This is because there are still many employees who have a high school education and equal. Also, in the aspect of informal education, it is necessary to increase the amount 
of time for employee competency training, courses, and internship programs abroad and in the country according to the needs and ability of employees.

Learning by doing can be healed with the help of leaders. In this case, the leader has a role to give tasks and guide employees to emerge in various special experiences in completing the work given. So that experience becomes new knowledge for employees in facing challenges in completing new tasks in the future.

Finally, by learning by investment, employees are expected to carry out a learning process by taking on "special" knowledge related to specific tasks given by the source of knowledge to individuals who are seeking knowledge. This process requires more resources and time so that a person can acquire new skills and techniques in dealing with a problem in his main work. From efforts to improve competence through individual knowledge acquisition supported by the role of transformational leaders, it is hope that they will be able to answer various problems that being faced, especially those related to the conditions of employee creativity as capital from creating product innovations with the aim of meeting product innovation and meeting the lack of number and unpreparedness of defense equipment and other main tools.

Based on the results of this study, the researchers hope that in the future this research can be developed by parties who have an interest in the concept of this research by considering the possible linkages of other relevant variables to be studied. Furthermore, the next researcher is expected not only to study permanent employees but also to involve respondents with contractual status and also with a larger population and research population than the previous research as a comparison. 


\section{REFERENCES}

Amabile, ST, 1998. 1988. A Model of Creativity and Innovation in Organization. Research in Organization Behaviour. Vol 10. Page 123-167.

Arikunto, S. 2010. Prosedur Penelitian Suatu Pendekatan Praktik . Jakarta: Roneka Cipta.

Bagheri et al. 2013. Analysis The Effect Of Individual Creativity On The Employees Engagement At Work (Case Study: Agriculture Organization Of Qom). International Journal of Accounting Research Vol. 1, No.2, 2013

Bass, MB, Avoilo, BJ, Jung, ID, Berson, Y. 2003. Predicting Unit Performance by Assessing Transformasional and Transactional Leadership. Journal of Applied Psychology. Vol. 88, No. 2, 207-218.

Creswell, W John. 2010. Research Design, Pendekatan Kualitatif, Kuantitatif, dan Mixed . Cetakan 1. Yorgyakarta: Penerbit Pustaka Pelajar.

Doeng, Y., Bartol, M, Kathryn., Zhang, Zhi-Xue., Li, Chenwei. 2016. Enchancing Employee's creativity Via Individual Skill Development and Team Knowledge Sharing: Influences of Dual-Focused Transformational Leadership. Journal of Organizational Behaviour, J. Organiz. Behav. DOI: 10.1002/job.2134.

E i senbeiss, AS, Boerner, Sabine. 2013. A Double-edge Sword: Transformational Leadership and Individual Creativity. Erschienen in: British Journal of Management ; 24, 1. - S. 54-68.

Farahbood, Fazrin., Ammoopour, Masoud., Koma, KLM 2012. Relationship of Knowloedge Management with Creativity of School Mangers. Journal of Basic and Applied Scientific Reaserch . 2(10)10549-10557.

Ford, Cameron, M. 1996. Theory of Individual Creativity Action in Multiple Social Domain. Academy of Management. The Academy of Management Review. October, 21,4 Page 1112.

Getzel, JW 1975. Problem-Finding and the Inventiveness of Solutions. The Journal of Creative Behaviour . 9 (1), 12-18.

Gong, Yaping., Huang, Ji-Chi., Farh, Jiing-Lih. 2009. Employee Learning Orientation, Transformational Leadership, and Employee Creatiity: The Mediating Role of 
Employee's creativity Self-Efficacy. Academy of Management Journal . Vol. 52, No.4, 765-778.

Gray, PH and Meister, DB 2004, Knowledge Sourcing Influenceiveness . Management Science, Vol. 50 No. 6, pp. 821-34.

Hsu, Ya-Ti. 2016. The Relationship Among Transformational Leadership, Employee's

Learning Abilities, Creativity, and Job Performance. Jou r nal og Human Resource Adult Learning , Vol 12, Num. 1, June.

Jain, Revindra., Jain, Cherry. 2017. Employee's creativity: A Conceptual Framwork. Management and Labour Studies . Business Management and Human Resources SAGE Publications. 41 (4) 249-313. DOI: 10.1177/0258042X16676664. Jyoti, Jeeven., Dev, Manisha. 2015. The Impact of Transformational Leadership on Employee's creativity: The Role of Learning Orientation. Journal of Asia Business Studies, Vol. 9 Iss 1 pp. 78-98.

Moghimi, Solmas., Subrimaniam, DI 2013. Employees Creative Behavior: The Role of Organizational Climate in Malaysian SME's. International Journal of Business and Management ; Vol 8, No. 5.http://dx.doi.org/10.5539/ijbm.v8n5p1 .

Mykytyn, J. P., Mykytyn, K., \& Raja, M. (1994). Knowledge acquisition skills and traits: a self-assessment of knowledge engineers. Information \& Management, n. 26, p. 95104.

Octavia, Lianna and Devie. 2015. Pengaruh Transformasional Leadership terhadap University Performance dengan Learning Organization dan University Culture Sebagai Variabel Intervening. Business Accounting Review, Vol. 3, No.1, 489-500.

Oldham, G.R. and Cummings, A. (1996) Employee Creativity Personal and Contextual Factors at Work. Academy of Management Journal, 39, 607-634.

Politis, D. John. 2002. Transformational and Transsactional Leadership Enabling (Disabling) Knowledge Acquisition of Selfmanaged Team: The Consequences for Performance. Ledership and Organizational Development Journal, Vol. 23 Iss 4 pp. 186-197. http://dx.doi.org/10.1108/01437730210429052soda .

Rahmatipour, A. Marjan., Alipour, M. Narges. 2015. Transformational Leadership Style and Knowledge Management Relationship among Tehran Hospital Libraries

\author{
Vol. 27, No. 3 December 2019 \\ (C) Centre for Indonesian Accounting and Management Research \\ Postgraduate Program, Brawijaya University
}


Manager. Journal of Humanities and Social Science (IOSR-JHSS) . Volume 20, Issue 6, Ver. IV, Jun.

Rondonuwu, A.(2011). Pengaruh Kepemimpinan Transformasional Dan Budaya Organisasi Terhadap Kepuasan Kerja Anggota Kepolisian Di Polres Bogor Kota. Tesis. Universitas Indonesia.

Rumbewas, Enias. 2016. Pengaruh Penempatan Kerja, Sistem Imbalan dan Motivasi Pegawai Terhadap Kinerja Pegawai . Disertasi. Malang; Universitas Brawijaya.

Rusly, F. H., Sun, P. Y. T., \& Corner, J. (2015). Change readiness: creating understanding and capability for the knowledge acquisition process. Journal of Knowledge Management, 19(6), 1204-1223. http://dx.doi.org/10.1108/ JKM-02-2015-0092

Shin, J. Shung., Zhou, J. 2003. Transformasional Leadership, Conservation, and Creativity: Evidance from Korea. The Academy of Management Journal , Vol. 46 No.6, Dec, pp703-714.

Sholihin dan Retno. 2012. Analisis SEM-PLS dengan WarpPLS 3.0. Yogyakarta: ANDI. Simola, S., Barling, J. \& Turner, N. (2012). Transformational Leadership and Leaders' Mode of Care Reasoning. Journal of Business Ethics, 108, 229-237. http://dx.doi.org/10.1007/s10551-011-1080-x

Singaribun, M \& Effensi, S. 2006. Metode Penelitian Survei. Jakarta: LP3ES.

Soda, Giuseppe., Stea, D., Pedersen, T. 2017. Network Structure, Collaborative Context, and Individual Creativity, Journal of Management, Vol. XX No. X, Month XXXX 1-27, DOI:10.1177/0149206317724509.

Sosik, J. John., Kahai, S. Surinder., Avolio, J. Bruce. 1998. Transformational Leadership and Dimensions of Creativity: Motivating Idea Generation in Computer Mediated Group. Creative Research Journal. Vol. 11, N0. 2, 111-121.

Sugiyono. 2010. Metode Penelitian Bisnis: Pendekatan Kuantitatif, Kualitatif, dan $R \& D$. Edisi 15. Bandung: Alfabeta.

Suifan, ST, Al-Janini, M. 2017. The Relationship Between Transformational Leadership and Employee's creativity in The Jordanian Banking Sector. International Review of Management and Marketing 7(2), 284-292. ISSN: 2146-4405.

Taylor, S. and Todd, PA 1995. Understanding Information technology usage: a Test of Competing Models, Information Sytems Reseach, Vol. 6, pp. 144-76. 